\title{
A MODEL OF TEACHER KNOWLEDGE FOR NONNATIVE ENGLISH-SPEAKING TEACHERS
}

\section{Luciana C. de OLIVEIRA*}

- Abstract: Despite an increasing interest in the preparation of Nonnative English-speaking (NNES) teachers in English Language Teaching (ELT), a knowledge base for NNES teachers has yet to be articulated. This article takes the position that the ELT field should take into account and address the preparation of NNES teachers systematically. This article conceptualizes a model of teacher knowledge for NNES teachers. NNES teachers are a special case because issues such as language, self-perceptions, and identity play a key role in their preparation and should be connected to their knowledge base.

- Keywords: Knowledge base. Nonnative English-speaking teachers. English Language Teaching.

\section{Introduction}

Nonnative English-speaking (NNES) educators have become more visible recently by bringing up their concerns regarding professionalism in ELT (KAMHISTEIN, 2009). The number of research studies and articles related to NNES teachers in TESOL has grown recently (BRAINE, 2010; KAMHI-STEIN, 2004; LIU, 2004). Teacher education programs often draw on specific knowledge and skills to prepare teachers for the profession. Research on teacher knowledge and preparation maintains a conception of teaching that includes a knowledge base for teaching. A knowledge base for NNES teachers has yet to be articulated. This article takes the position that the ELT field should take into account and address the preparation of NNES teachers systematically. One way to do so is by creating a taxonomy for NNES teacher knowledge. NNES teachers are a special case because issues such as language, self-perceptions, and identity play a role in their preparation and should be connected to their knowledge base.

\footnotetext{
* University of Miami University Drive. School of Education and Human Development - Department of Teaching and Learning. Coral Gables - FL - United States.33124 - ludeoliveira@miami.edu.
} 


\section{The term "nonnative English-speaker"}

The labels "native" and "nonnative" have been under scrutiny in the research literature and some would argue that they are problematic (BRUTT-GRIFFLER; SAMIMY, 1999; LIU, 2004) and fairly useless. The notion that "native" English speakers are better teachers of English because of their fluency, idiomatic knowledge, and cultural awareness has been under examination (PHILLIPSON, 1992). This tenet is known as "the native speaker fallacy" (PHILLIPSON, 1992). There is also little agreement as to what the term "native speaker" refers. However, those that are perceived as speaking another language as their first/home language are often labeled as NNES (PASTERNAK; BAILEY, 2004). Many NNES teachers are international students, whose needs have been neglected in TESOL programs (LIU, 1998).

\section{A Knowledge Base for Teaching ESL/EFL}

Significant agreement about the major components of a knowledge base for teaching has been achieved in general teacher education, although different models may differ in some aspects. Bransford, Darling-Hammond, and LePage (2005, p.11) provide a framework for understanding the general knowledge, skills, and dispositions for all teachers:

a. knowledge of learners and their development in social contexts: knowledge about learning, human development and language;

b. knowledge of subject matter and curriculum goals: knowledge about educational goals and purposes for skills, content, and subject matter;

c. knowledge of teaching: knowledge about teaching subject matter, teaching diverse learners, issues of assessment, and classroom management.

These three components indicate that there is a common foundation of knowledge for teachers. Two variables need to be included when we consider the specific case of teaching ESL/EFL: the special case of English language as content and process and the case of students being speakers of other languages. Knowledge about language can be conceptualized as content knowledge, the knowledge teachers have of the subject matter, and the application of knowledge about language can be seen as pedagogical content knowledge. But this distinction is not enough to demonstrate the complexities involved in this "knowledge about language". Four areas that add to the knowledge base for teaching are: (a) knowledge of teachers as learners of language teaching, (b) teacher practice and knowledge of self, (c) knowledge and understanding of language learning and assessment, and (d) procedural and declarative knowledge about language. 
(a) Knowledge of teachers as learners of language teaching. One dimension added to current knowledge base models is the first domain described by Freeman and Johnson (1998), the consideration of teachers as primary learners of language teaching. This work contributes to other knowledge base models the dimension of considering teachers as learners.

(b) Teacher practice and knowledge of self. Language teacher education researchers focus on teachers' instructional actions and their connections to teacher learning (GOLOMBEK, 1998; PENNINGTON, 1995). Pennington (1995) and Golombek (1998) studied teacher practice and change, in which teachers' instructional actions were examined in the context of critical reflection and dialogue about those actions. Teaching practices progress from technical matters to classroom roles and relationships (PENNINGTON, 1995) and help teachers examine their actions and tensions derived from their practices (GOLOMBEK, 1998). A teacher's knowledge of self in learning to teach along with teachers' practice can illuminate a knowledge base for teaching.

(c) Knowledge and understanding of language learning and assessment. In P-12 (preschool through $12^{\text {th }}$ grade) ESL teacher preparation, teacher education program standards have been developed for the purpose of accreditation of teacher education programs. Approved by the National Council for Accreditation of Teacher Education (NCATE) and the TESOL Board of Directors in October 2001 and published online in 2003, these standards were revised and approved in 2010 (TESOL, 2010). Developed based on recent research in the areas of language learning, culture, and assessment, the TESOL/NCATE Standards document can be taken as a model for a knowledge base for teaching ESL and shows many points about what ESL teacher candidates must know and understand about language.

ESL teachers must display knowledge in the domains of language learning, such as language for communication, connections between academic content and language, and selection and use of meaningful content in teaching. Knowing and understanding the backgrounds of ESL learners and their communities are also important components for planning and providing instruction to them (TARONE; ALLWRIGHT, 2005).

Knowledge of assessment is a central category in the standards for ESL teachers. Teachers must be able to assess the academic achievement of ESL learners in the initial stages of learning as well as use different assessment techniques in different educational levels. In addition to assessment of ESL learners' sociocultural competence (TESOL, 2010), teachers must recognize students' needs in this area and assist their development of appropriate norms and customs. Assessment of language proficiency and academic achievement and use of a variety of assessment techniques are key components of knowledge of assessment.

(d) Procedural and declarative knowledge about language. Another model to explore teachers' attributes is Pasternak and Bailey's (2004), who frame their discussion of issues of professionalism and proficiency around procedural and declarative knowledge. Declarative knowledge is knowledge about something; it refers to the things we know 
and are able to articulate (PASTERNAK; BAILEY, 2004). Procedural knowledge is knowledge of how to do something; it refers to the skills we possess or our ability to do things (PASTERNAK; BAILEY, 2004). An example of procedural knowledge would be a teacher's ability to speak the language and declarative knowledge would refer to the teacher's knowledge about the language, for example, the ability to articulate specific rules of the language. Part of the declarative knowledge of language teaching would include knowledge about the target language and culture and about teaching. This distinction between declarative and procedural knowledge provides a framework for assessment of areas that need improvement. It can be assumed that an ESL/EFL teacher's confidence is dependent upon his/her procedural and declarative knowledge in any given area of ELT (PASTERNAK; BAILEY, 2004).

\section{The Knowledge Base for Teaching ESL/EFL: The Case of NNES Teachers}

\section{Factors affecting NNES professionals}

In addition to research in teacher education, several issues related to NNES teachers have been explored in recent years (KAMHI-STEIN, 2009; LIU, 2004), including the importance of identity, identity construction, and knowledge of self in the context of NNES teacher education.

Identity and identity construction have been investigated, with a special focus on learners rather than on teachers. Identity formation is an ongoing process involving the interpretation and reinterpretation of experiences. It is through the interaction with others, an individual's development over time and her own self-evaluation that one's identity is continually informed and reformed. One's self-image is influenced by self-evaluation and identity.

Social identity is defined by Norton (1997, p.420) as "the relationship between the individual and the larger social world, as mediated through institutions such as families, schools, workplaces, social services, and law courts" and how this relationship is changed and built across time and space. Norton (1997, p.420) explains the distinction between social identity and cultural identity: "Cultural identity [is used]... to refer to the relationship between individuals and members of a group who share a common history, a common language, and similar ways of understanding the world". Based on these definitions, it is important to consider not only the perceptions of others (PASTERNAK; BAILEY, 2004) but also how speakers of a language other than English perceive themselves. These speakers may recognize that being "nonnative speakers of English" is part of their social and cultural identity. For instance, those who self-identify as nonnative may share common characteristics and attributes that make them part of the same group. Some individuals may share more characteristics than others, but the idea that they "belong" to the same group is an important one to consider. 
Since knowledge of self is an integral part of the knowledge base for teaching, it can be argued that identity and identity construction should be explored by NNES teachers. According to Liu (2004), NNES teachers may go through changing, multiple identities. Liu, reflecting on his experiences as a NNES professional and the process of "cultural transformation" discusses the changes in his identities depending on the context where he was. Another related issue of significance is NNESs' perspectives on their own skills and abilities in the second language (LIU, 2004). Kamhi-Stein (2009) shows four major points in the area of NNES teachers-in-preparation perceived needs and strengths: low confidence and self-perceived challenges to professional competence, their language needs, lack of voice and visibility in TESOL, and selfperceived prejudice based on ethnicity or nonnative status. One of the challenges faced by NNES teachers-in-preparation is language anxiety, particularly in reading, writing, and speaking. Besides issues of identity, all of these points, associated with NNES teachers' needs and strengths, can also be considered aspects of NNES teachers' knowledge of self.

One issue addressed in understanding NNES educators' self-perceptions has been the interplay between English proficiency and professional preparation, which should be regarded as continua (PASTERNAK; BAILEY, 2004). Language proficiency is only one aspect of the professional preparation of NNES teachers. Teachers also need the appropriate education to be a language teacher.

\section{English language proficiency and the professional preparation of NNES teachers}

Recently developed professional standards reflect some components of a knowledge base for teaching. Two of TESOL/NCATE Standards (TESOL, 2010), Standard 1a and $5 \mathrm{~b}$, specifically relate to the issue of language proficiency by ESOL teachers:

Standard 1.a. Language as a System

Candidates demonstrate understanding of language as a system, including phonology, morphology, syntax, pragmatics and semantics, and support ELLs as they acquire English language and literacy in order to achieve in the content areas. (TESOL, 2010, p.27)

Standard 5.b. Professional Development, Partnerships, and Advocacy

Candidates take advantage of professional growth opportunities and demonstrate the ability to build partnerships with colleagues and students' families, serve as community resources, and advocate for ELLs. (TESOL, 2010, p.71)

These standards clearly show the importance of language proficiency by ESOL professionals. By the end of their teacher preparation programs, teacher candidates 
must display a "high level" of English proficiency so that they can serve as "strong models of academic English language proficiency" and "good language models" for their students. This document clearly calls for teacher candidates' language skills to be considered and developed, if necessary, by P-12 teacher education programs. It could be argued that any language teacher education program should also take these standards into consideration when addressing issues of language proficiency. KamhiStein (2009) calls for a language training component in TESOL preparation programs to provide NNES teachers-in-preparation with focused instruction in areas they will need in the profession.

Language proficiency and NNES teachers' perception of their proficiency are strong factors in classroom performance (KAMHI-STEIN, 2009). Low confidence and language anxiety are two recurring issues described by NNESs. According to Murdoch (1994), language proficiency is the foundation of NNESs' confidence. If this is true, working on NNESs' language skills can only help NNESs' professional lives, since NNESs' confidence will increase and their reported language anxieties decrease. Because language proficiency is important for NNES teachers' professional lives (in preservice programs and at the job market), a focus on NNESs' language needs must be part of any effective teacher education program.

\section{A Model of NNES Teacher Knowledge}

A specific model of NNES teacher knowledge based on the different models of teacher knowledge reviewed and the current research in teacher education and NNES issues is described next. Figure 1 describes the domains of a tentative model of NNES teacher knowledge for teaching ESL/EFL. 
Figure 1 - A Model of NNES Teacher Knowledge

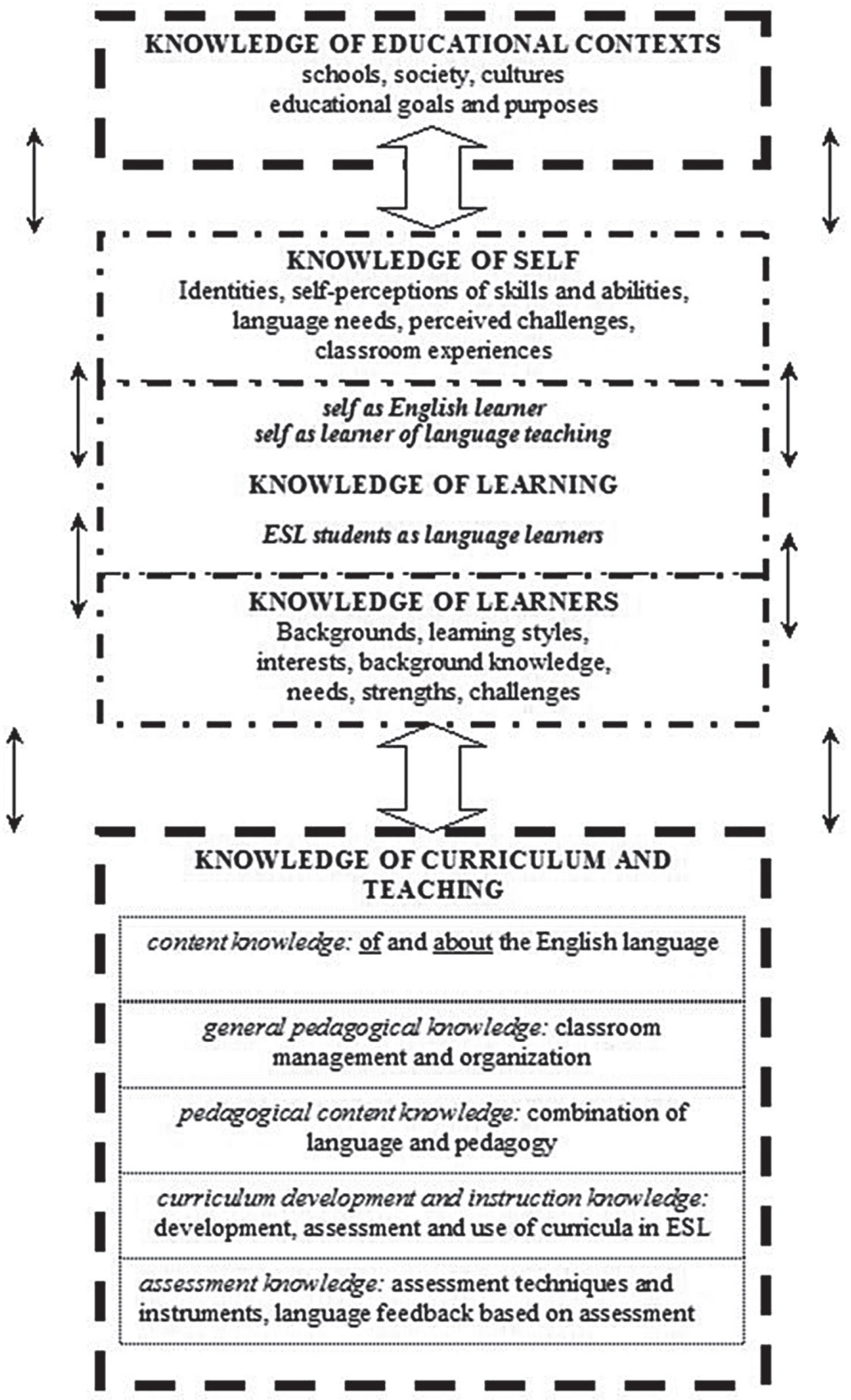

Source: Author's elaboration. 
A model of NNES teacher knowledge for teaching ESL/EFL is demonstrated in Figure 1. The figure is divided into five main domains: knowledge of educational contexts, knowledge of self, knowledge of learning, knowledge of learners, and knowledge of curriculum and teaching. The first category is at the base of the model, knowledge of curriculum and teaching, which encompasses several knowledge areas.

Knowledge of curriculum and teaching is the general category that involves all different aspects related to teaching and the core knowledge that a teacher needs. It follows Freeman and Johnson's (1998, p.397) call for a rethinking of language teacher education in which the practice of teaching is central: "We argue that the core of the new knowledge-base must focus on the activity of teaching itself..." The first domain under this category is content knowledge, which includes knowledge of and about the English language. Knowledge of the English language refers to the skills of a person in terms of what she can do with language. It is what Pasternak and Bailey (2004) call procedural knowledge; for instance, knowledge of how to use verb tenses appropriately. Language proficiency would go under this domain. Knowledge of English incorporates knowledge of language features that NNES teachers will frequently use in classroom teaching and other classroom discourse features important for delivery. Knowledge about language refers to the knowledge a person develops in contexts where learning is focused on language itself, i.e. a person's ability to explain the English language. This refers to what Pasternak and Bailey (2004) calls declarative knowledge or knowledge about something; for instance, explaining the use of verb tenses in English and when one choice is more appropriate than another. It is especially important for NNES teachers in an ESL context to have both knowledge of and about the English language because English will be used as the medium of learning in such contexts. In job interviews and classroom observations, NNES teachers will be assessed by not only what they are teaching (the content) but also by how they are using language to explain specific content. In explaining this model, I highlight the special language piece.

The second category of NNES teacher knowledge is knowledge of learners, a key component (TARONE; ALLWRIGHT, 2005). Teachers must be aware of and understand the backgrounds of students they will potentially teach. They must understand students' learning styles, background knowledge, needs, strengths and challenges in their learning of ESL/EFL and be familiar with the different communities from which students are coming.

The third category is at the center of the model, knowledge of learning. This category is placed between the second category, knowledge of self, and the fourth category, knowledge of learners, to illustrate the relationship between these three components. It is placed at the center because it is the most central category for NNES teachers. Two key areas are included under knowledge of learning: NNES teachers as English learners and as learners of language teaching and ESL/EFL students as English learners. NNES teachers must reflect on their own experiences as English learners, possibly use those experiences in the classroom, but also consider and recognize the potential differences 
between themselves and their own learning of English and their students' experiences and learning. NNES teachers must realize that their instructional actions are connected to their own learning and attend to not only students' learning but also their own learning based on their teaching experiences in the classroom. ESL/EFL students as English learners refers to students' learning and involves comprehension of students' potential difficulties in learning English and the impact of individual differences in learning. Knowledge of learning also involves being familiar with learning theory and learning differences.

Knowledge of self is a key component of NNES teacher knowledge, the fourth category in the model. NNES teachers' understanding of their identities, self-perceptions on their own skills and abilities in the second language, language needs, perceived challenges, and experiences are key components of this domain. It is important to recognize the interplay between knowledge of self and knowledge of learning. One of the components of knowledge of self is understanding NNES' self-perceptions and language needs. NNES teachers' self-perceptions are connected to their confidence. If language proficiency is the foundation of NNESs' confidence, NNES teachers must not only understand their self-perceptions and language needs, they must also work on their language skills. NNES teachers must continue their own learning of English and improve their language proficiency. I have included language proficiency as part of content knowledge in this model of teacher knowledge. Here we see an example of the interaction between areas of knowledge: Knowledge of self is connected to language proficiency, which is part of content knowledge.

At the top of the figure is the last domain, knowledge of educational contexts, which includes familiarity with various contexts which will potentially be sites where teachers might choose to teach. These comprise different classrooms and schools, including their structural organization. NNES teachers going through a TESOL program might choose to live overseas and, therefore, must also have some understanding of the differences between ESL and EFL contexts. The double pointed arrow linking this domain to knowledge of self in the figure shows that NNES teachers must also recognize the educational contexts where they have learned English so they can understand the differences and similarities between those contexts and the ones where they will potentially teach.

The boundaries among the domains presented in the model are not as definite as they may appear to be in the figure. Domains influence and are influenced by each other, which is shown by the use of doted lines. These interactions across areas of knowledge are also demonstrated by the double-sided arrows linking the three main parts of the figure. In addition, several smaller double-sided arrows on the left and right sides of the five categories were used to illustrate their continuity. Although the discrete categories in this framework of NNES teacher knowledge are useful at a conceptual level, in practice the various forms of teacher knowledge interact in complex ways in teachers' practice. 
There certainly are many skills and abilities that a new teacher must have. The goal of this section was not to provide a definite and fixed model of NNES teacher knowledge. The intent of this section was to highlight some main areas of significance that teacher educators should take into account when preparing NNES teachers based on the research literature on both teacher education and NNES teachers. Conceptualizing a model of NNES teacher knowledge involves showing the importance of certain components and emphasizing the need to incorporate knowledge of selfinto a knowledge base for NNES teachers. The inclusion and recognition of knowledge of learning and knowledge of self as key components of a knowledge base for NNES teachers is a major contribution of this article to the research literature.

\section{Implications for Teacher}

Many NNES students are attracted by TESOL and Applied Linguistics programs all over the world. The linguistic demands of academic programs may be challenging for NNES teachers in preparation. Many such programs still do not systematically incorporate issues that address the needs and concerns of NNES teachers-inpreparation (KAMHI-STEIN, 2009). TESOL programs can provide NNES teachersin-preparation with opportunities to voice their concerns and to discuss issues of interest to them. Two options are suggested by researchers in NNES teacher preparation: integration of these issues within a variety of classes throughout the TESOL curricula (KAMHI-STEIN, 2009) and a seminar offered to NNES teachers-in-preparation where they are required to write a "professional autobiography" in order to examine their experiences as L2 learners (BRUTT-GRIFFLER; SAMIMY, 1999). An addition of such issues would benefit the preparation of NNES teachers and show that these are important topics that should be addressed by the TESOL field.

NNES future teachers' knowledge of self should be an integral part of a teacher education program. Issues related to NNES teachers should be addressed throughout the TESOL curricula. Knowledge of self involves an understanding of NNES educators' self-perceptions and examination of their own identities, language needs and concerns. Each TESOL class can devote class time to discuss NNES-related issues. Different articles can serve as the basis for critical discussion by future teachers, both native and nonnative.

Another important area to be considered is academic language development. Being strong models of academic English language proficiency requires development of academic language by NNES teachers. Academic language refers to the language used in the learning of academic content in school contexts and it usually includes aspects of language associated with academic achievement and literacy skills as well as lexicon specific to schooling contexts. In terms of NNES language proficiency, TESOL programs can focus on the expectations of academic discourse by providing many models of effective presentations done by previous NES and NNES teachers- 
in-preparation. NNES teachers can focus on discourse features needed for effective spoken communication and used in more formal presentations and informal spoken interactions with other students and the instructor. By providing models of successful presentations and interactions, TESOL programs will be enabling NNES teachers to focus on language resources they will need in order to be better prepared for classroom interactions. NNES practicum participants can attend to the classroom discourse structures necessary for effective teaching. If language proficiency is really the foundation of NNESs' confidence (MURDOCH, 1994), these concentrations may help NNES teachers become more confident in their own language abilities and, as a consequence, may increase their effectiveness in teaching. Working on NNESs' language skills can only facilitate NNESs' professional lives.

It is important to note that those who self-identify as nonnative may share common characteristics and attributes. However, self-identification as nonnative speakers does not equate to absolute characteristics; individual differences are an important consideration (KAMHI-STEIN, 2004). A focus on teacher development that moves beyond a "deficit model," in which evaluations of teachers are based on individual teachers' competence, i.e. qualifications they possess, and deficits, i.e. qualifications they do not possess is necessary. At the same time, it is important to focus on what NNES teachers need to know and be able to do.

Rather than a static body of knowledge, as the term "knowledge base" might imply, the model of NNES teacher knowledge presented here organizes teaching and learning as a process in which understanding is constructed through teachers' experiences and knowledge of self. It suggests an ongoing interaction between teachers' knowledge and actions and their awareness of self, their own learning, and students' learning. Teacher knowledge, then, should not be seen in isolation; this framework suggests a complex interaction among the different areas of knowledge. Taking Freeman and Johnson's (1998) position that teacher knowledge can and should be rooted in teachers' actual practice, this article is written with the belief that teachers will develop a knowledge base that matures and gains texture with teachers' experiences and preparation. Whereas the identification of particular components of knowledge is certainly necessary, it is not sufficient. I hope this article starts the discussion about a knowledge base for NNES teachers in ELT.

\section{UM MODELO DE CONHECIMENTOS PARA PROFESSORES NÃO-NATIVOS DE INGLÊS}

- Resumo: Apesar do interesse crescente na preparação de professores não-nativos de inglês (NNI) na área de ensino de inglês (EI), uma base de conhecimentos para professores NNI ainda tem que ser articulada. Esse artigo tem como posição que a área de EI deve levar em consideraçáa a preparação de professores NNI sistematicamente. Esse artigo conceitualiza um modelo de 
conhecimentos para professores NNI. Professores NNI são um caso especial porque questöes como aprendizagem de lingua, percepçóes próprias e identidade têm um papel fundamental em sua preparação e devem estar conectadas as suas bases de conhecimento.

- Palavras-chave: Base de conhecimento. Professores näo-nativos de inglês. Ensino de língua inglesa.

\section{REFERENCES}

BRAINE, G. Nonnative Speaker English Teachers: Research, pedagogy, and professional growth. New York: Routledge, 2010. 128p.

BRANSFORD, J.; DARLING-HAMMOND, L.; LEPAGE, P. Introduction. In: DARLINGHAMMOND, L.; BRANSFORD, J. (Org.). Preparing Teachers for a Changing world: What teachers should learn and be able to do. San Francisco: Jossey-Bass, 2005. p.1-39.

BRUTT-GRIFFLER, J.; SAMIMY, K. Revisiting the colonial in the postcolonial: Critical praxis for nonnative-English-speaking teachers in a TESOL program'. TESOL Quarterly, Malden, v.33, n.3, p.413-431, 1999.

FREEMAN, D.; JOHNSON, K. Reconceptualizing the knowledge-base of language teacher education. TESOL Quarterly, Malden, v.32, n.3, p.397-417, 1998.

GOLOMBEK, P. R. A study of language teachers' personal practical knowledge. TESOL Quarterly, Malden, v.32, n.3, p.447-464, 1998.

KAMHI-STEIN, L. D. Teacher preparation and nonnative English-speaking educators. In: BURNS, A. A.; RICHARDS, J. C. (Org.). The Cambridge Guide to Second Language Teacher Education. New York: Cambridge University Press, 2009. p.91-101.

Learning and Teaching from Experience: perspectives on nonnative Englishspeaking professionals. Ann Arbor: University of Michigan Press, 2004. 360p.

LIU, J. Confessions of a nonnative English-speaking professional. In: KAMHI-STEIN, L. D. (Ed.). Learning and Teaching from Experience: perspectives on nonnative English-speaking professionals. Ann Arbor: University of Michigan Press, 2004. p.35-47.

. Ethnocentrism in TESOL: Teacher education and the neglected needs of international TESOL students. ELT Journal, Oxford, v.52, n.1, p.3-10, 1998.

MURDOCH, G. Language development provision in teacher training curricula. ELT Journal, Oxford, p.48, n.3, p.253-259, 1994.

NORTON, B. Language, identity, and the ownership of English. TESOL Quarterly, Malden, v.31, n.3, p.409-429, 1997. 
PASTERNAK, M.; BAILEY, K. M. Preparing nonnative and native English speaking teachers: Issues of professionalism and proficiency. In: KAMHI-STEIN, L. D. (Ed.). Learning and Teaching from Experience: perspectives on nonnative English-speaking professionals. Ann Arbor: University of Michigan Press, 2004. p.155-175.

PENNINGTON, M. The teacher change cycle. TESOL Quarterly, Malden, v.29, n.4, p.705731, 1995.

PHILLIPSON, R. Linguistic Imperialism. Oxford: Oxford University Press, 1992. 376p.

TARONE, E.; ALLWRIGHT, D. Second language teacher learning and student second language learning: Shaping the knowledge base. In: TEDICK, T. J. (Ed.). Second Language Teacher Education: international perspectives. Mahwah: Erlbaum, 2005. p.5-23.

TEACHERS OF ENGLISH TO SPEAKERS OF OTHER LANGUAGES, INC [TESOL]. TESOL/NCATE standards for the accreditation of initial programs in P-12 ESL teacher education. 2010. Available at: <http://www.tesol.org/docs/books/the-revised-tesol-ncatestandards-for-the-recognition-of-initial-tesol-programs-in-p-12-esl-teacher-education-(2010pdf).pdf?sfvrsn=2>. Access on: 21 may 2015. 
